\title{
Two models of structural epistemology: Russell and Zhang Dongsun
}

\author{
Jana Rošker ${ }^{1}$
}

Received: 14 June 2015/Revised: 8 July 2015/Accepted: 9 July 2015/Published online: 23 July 2015 (C) Academy for International Communication of Chinese Culture and Springer-Verlag Berlin Heidelberg 2015

\begin{abstract}
Zhang Dongsun (1886-1973) who belongs to the leading Chinese philosophers of the twentieth century, has developed his own system of thought, based upon the so-called pan-structural epistemology according to which the external cause of our sensation is not a substance, but the structural order of the external world. In his Introduction to Mathematical Philosophy (1919), Russell had proposed a similar idea. The present article is based upon a comparative analysis of both structural epistemology models and aims to determine the specific and unique features of Zhang's theory, focusing upon the elements deriving from traditional Chinese thought. Although in his pluralistic epistemology Zhang rejected 'substance', he namely still considered the dualistic theories of idealism and materialism to be completely wrong. While elements of both approaches can be found in Zhang Dongsun's model, it cannot be identified with either one of them.
\end{abstract}

Keywords Modern Chinese theories of knowledge - Zhang Dongsun · Pan-structuralism $\cdot$ Structural epistemology

\section{Introduction}

While Zhang Dongsun 張東荪 (1886-1973) can also be considered as one of the leading Chinese philosophers of the twentieth century, his criticism of sinificated Marxist ideologies marked him as a political dissident and he was consequently consigned to oblivion for several decades; only recently has his work been rediscovered by a number of younger Chinese theorists, who have shown a growing interest in his ideas. During the first three decades of the twentieth century, Zhang

Jana Rošker

jana.rosker@ff.uni-lj.si

1 Faculty of Arts, University of Ljubljana, Aškerčeva 2, 1000 Ljubljana, Slovenia 
was one of the most influential thinkers of the Republic of China, a reputation which rested, in part, on his extraordinary ability to introduce Western thought in a way which was compatible with the spirit of Chinese tradition.

\section{Pan-structuralism (Fanjiagouzhuyi 泛架構主義)}

Pluralistic epistemology represents the core of Zhang's philosophical system. His pluralism is derived from a revised version of Kantian philosophy. To justify such an epistemology, he proposed a new cosmology: pan-structuralism (Jiang 2002, p. 58).

An important assumption of his theory of knowledge is the neo-realistic view that the external world exists independently of our consciousness, and that there is no exact correlation between external phenomena and our comprehension of them. Hence, we are unable to perceive these phenomena as they really are.

According to Zhang, the external cause for our sensation is not a substance, but the order or structure of the external world. What is transmitted to us through our sensory impressions is a modification of this external order. In interpreting the basic structure of reality, he also referred to scientific discoveries regarding atoms and their most elementary structures, which transcend the categorical boundary between particles of matter and non-substantial electromagnetic waves. Here, his critique of substance was quite radical, and he denied the real existence not only of the smallest particles of matter, but also of quantums, electrons and even electromagnetic waves (Zhang 1995, pp. 168-169). Similarly, the discovery of the Theory of Relativity was important only in terms of recognizing structural laws, and not in terms of recognising any new essences in nature or the cosmos. The denial of substance also refers to the sphere of ideas. As in Chan Buddhism, all that we perceive is not only empty in the sense of substantial absence, but also illusory. Therefore, Zhang's cosmology is neither materialistic, nor idealistic (ibid. p. 214).

According to Zhang, one reason for our inability to recognise the essence of external things "as such" is thus to be found in the very nature of their existence; for Zhang, who did not acknowledge the existence of substance, reality was a process of constant changes that manifests itself in the inter-relations of particular entities. His cosmology is not metaphysical. In his view, this constituted another difference between Kantian philosophy and his own. In Kant, metaphysics is not abandoned, even though the priority given to epistemology radically alters its role. Zhang's revision of Kant is, in fact, limited to the Kantian theory of knowledge. In his ontology, the Chan-Buddhist impact is much stronger. In his early youth, his reading of Buddhist sacred texts got him interested in philosophy. Although he would criticize Buddhism severely later on, he always seemed to have accepted much of Buddhist cosmology, especially certain ideas from the Great Vehicle School (Mahayana) (Jiang 2002, p. 63).

Because he rejected the existence of substance, according to him, the objects perceived by us can not possess any "ontological status" (Zhang 1995, p. 215). All beings exist in a process of constant change that manifests itself in a never-ending modification of structural connections, and the growth and decline of the qualities of the "essence" of particular entities. According to Zhang, our consciousness can only 
recognize certain aspects ${ }^{1}$ of these manifest changes. However, this refers not only to the level of our perception and comprehension; according to Zhang, the structured order of relations is all that really exists in the cosmos.

Zhang argued that all these structures are empty, for they possess neither substance, nor its qualities. The level of material being (wu 物) is thus a merely physical substantial phenomenality which cannot be equated with material substance, but, at the most, with structural relations and the physical laws which determine its existence. For him, "matter" is a general concept comprising a total domain of many specific concepts about physical properties. There is nothing in matter itself which corresponds to our concept of matter. It is not the colour, fragrance, sound or size that we perceive through our senses, because they tend to be subjective. Therefore, by "matter" he understood an object's volume, density, or speed. Thus, in his view, matter becomes little more than a set of physics formulas. Therefore, there are only physical laws, but no matter (Jiang 2002, p. 64).

All external structures are manifested in our mind, that (re)-establishes them in the process of forming structural patterns of thought and comprehension. However, Zhang's theory is not solipsistic, since the external reality for him is not an exclusive product of our recognition (Zhang 1995, p. 171). Thus, similar to the holistic approaches that have prevailed in classical Chinese philosophy, Zhang also presumes that the relation between the external world and our subjectivity is interactive and correlative (ibid, p. 218).

\section{Western influences: from Kant to Russell}

We can assume that the basic inspiration for Zhang Dongsun's pan-structural theory of knowledge derived directly from his expertise in Western epistemological discourses which, during this period, were exerting a decisive influence on the search for new paradigms for the perception, comprehension and interpretation of reality. We must therefore correct Zhang Yaonan's evaluation of pan-structuralism (2000, p. 143), in which he claims that Zhang Dongsun's system was a pioneering achievement in the field of international structuralism, and that he had explored structuralist methods in ontology and in the theory of knowledge "almost 40 years before the appearance of Western 'structuralism"” (ibid.), which then became one of the leading discourses in Europe and America. ${ }^{2}$

In the 1920s, Zhang Dongsun (1902-1973) established a cosmological structuralism, which he called the 'Theory of Structure'. Over the next 20 years,

\footnotetext{
${ }^{1}$ These aspects are atomicity (yuanzixing 原子性), continuity (lianxuxing 連續性) and creativity (chuangbianxing 創變性). The cosmos also possesses the quality of (latent) plasticity (kesuxing 可塑性), which is passive in nature and does not belong to the external order; therefore, it cannot be perceived or comprehended directly (Zhang 1995, p. 168).

220 世紀20年代, 張東孫先生 (1902-1973) 提出了一種他稱之為 '架構論' (Theory of structure) 的 '結構主義' (structuralism) 宇宙觀, 並在以後20年間不斷完善, 使其成為 他 本人終生不願放棄的幾 個基本觀念之一. 就時間上說, 這一 宇 宙觀的正式形成要比西方 結構主義, 風行歐美 (20世紀60年 代) 早出將進 40 年; 就內容上說, 這一宇宙觀完全改變了二十世紀 中國 哲學家的固有思維方式, 開 了二十世紀中國哲學’非本 體論化’ 的先河. (Zhang 2000, p. 143).
} 
he continued to elaborate this theory as one of his basic paradigms, and would not abandon it until the end of his life. We should point out that this theory was elaborated almost 40 years before the appearance of Western 'structuralism', which then became one of the leading discourses in Europe and America. In its content, this cosmology completely changed the previous mode of thinking of twentieth century Chinese philosophers and was a precursor for the new 'deontological' approaches of Chinese philosophy". Obviously, structuralism in the sense of an integral and substantial paradigm of academic research and an independent branch of Euro-American discourse did not appear in a significant way until the latter half of the twentieth century, but a structural approach to comprehension had certainly been developed in Western philosophical systems nearly a half century earlier, especially in the theories of the British philosopher Russell (1919, 1957).

Although Zhang Dongsun acknowledged that his (pan) structural epistemology was partly derived from the philosophy of Immanuel Kant. ${ }^{3}$

I believe that we cannot obtain regulated (structured) recognition through sensory perception-in this respect, I agree with Kant. On the other hand, this regulation (structuredness) can not arise entirely from the synthetic ability of our mind-in this respect, I disagree with Kant. Therefore, I acknowledge that the external world is ordered and that our inwardness (i.e. our mind) also functions in accordance with particular laws. This regulated constitution of our inwardness can also be divided into two kinds: the first can be called the a priori form of direct sensory perception, and the second the a priori form of cognition./Here, again, my view is similar to Kant's/. However, the sensations are not identical with 'existing beings'. Since my theory arose from many different aspects, I have named it a 'pluralistic theory.See also Jiang Xinyan: 'His pluralism is derived from a revised version of Kantian philosophy. To justify such an epistemology, he proposed a cosmology: panstructuralism" (Jiang 2002, p. 58), he almost never mentioned Russell's philosophy, even though he must have been quite familiar with his work, since he had accompanied the British philosopher on his lecture tour in China in 1920-1921 (see Russell 2000). In addition to the influence of Western philosophy, and despite the differences between the two structural epistemologies which we will indicate schematically below, in Zhang Dongsun's pan-structuralism we can also clearly detect the influence of both Chan Buddhism ${ }^{4}$ and the autochthonous, classical philosophy ${ }^{5}$ of ancient China.

\footnotetext{
3 我主張感覺不能給我們以條理的知識,這雖跟康德相同, 但條理卻不能完全是心的綜合能力所產, 這又和康德不同了. 因此我承認外界有其條理; 內界 (即心)亦有其立法; 內界的立法又分兩種,一為直 觀上的先驗方式,一為思維上的先驗方式. (這一點與康德相似).至於感覺, 則不是真正的'存在者'.所 以我此說有幾個方面,因名之曰多元論 (Zhang 1995, p. 165).

${ }^{4}$ As a youth, it was Buddhist scriptures such as Leng Yan Jing and Da Cheng Qi Xin Lun that led him to be interested in philosophy. Although he criticized Buddhism later on, he seemed always to have accepted Buddhist cosmology, especially certain ideas from the Great Vehicle School (Mahayana, dacheng) (Jiang 2002, p. 63).

${ }^{5}$ Nonetheless, Zhang still managed to remain rooted in his own tradition. In his youth, he had obtained a very solid classical Chinese education (Rošker 2008, p. 301).
} 


\section{Two kinds of structural epistemology}

As we have seen, in Zhang's epistemology the external cause of our sensation is not a substance, but the structural order of the external world. What is transmitted to us through our sensory impressions are modifications of this external order (Jiang 2002, p. 59). Russell had proposed a similar idea (1919) in his Introduction to Mathematical Philosophy:

Against the then dominant claims that only the phenomena ("the world of percepts") can be known and that, even if they exist, their "objective counterparts" are unknowable, Russell (1919, 61) suggested that "the objective counterparts would form a world having the same structure as the phenomenal world, [a fact which would allow us] to infer from the phenomena the truth of all propositions that can be formulated in abstract terms and which are known to be true of the phenomena (Psillos 2001, p. 14).

But while, based on this supposition, Russell concluded that the recognition of external objects could allow us to infer the reality of all propositions that can be expressed on this abstract level, Zhang cautioned that this problem could not be solved so easily, since everything that was transmitted to us through our senseconditioned impressions were modifications of this external structural order. Therefore, because objects cannot be recognized in a one-dimensional way, we are incapable of comprehending the internal nature (or essence) of the external reality, but can only recognize its relations, which form a relatively fixed structure. And this impossibility of recognizing the substance of external objects is due not only to the limits of our sense organs, but also to the fact that these objects as such, even though they exist objectively, do not possess any substance.

若我們暫假定物質并無 內性，而只是架構，則我們已可謂知道外物了 (Zhang 1929, p. 32).

If we assume that the qualities of things do not possess any inner nature (essence), and that things only exist as a structure, we have already recognized the external reality.

In this respect, Zhang's epistemology differs considerably from Russell's (1919) system, which only presumes the possibility of inferences leading from the structure of the phenomenal world to the structure of objective reality. It does, however, resemble Russell's later, more elaborated thesis (1929) on the objective nature of conceptions within the mind.

By 1921, Russell had assigned the role of logical atoms to events, the more neutral, neither definitely physical nor definitely mental elements, that fitted nicely with his newly discovered affection for neutral monism. Moreover, he had assigned the role of the objects of direct recognition to percepts, or those events that occurred within one's head (Votsist 2003, p. 879).

But Russell's structural theory of perception, which he introduced in his book The Analysis of Matter (1927), remains focused upon logical inferences as the only 
possible link between objective reality and consciousness. In this work, he advocates a causal theory of perception, asserting that even though it is reasonable to presuppose the existence of causes (entities) outside our mind, we still cannot expect proofs for the supposition that things perceived by us are necessarily produced by external causes. And while we can directly recognize the inner nature or quality (the first order of properties and relations) of the objects perceived, this in no way means that the same holds true for the entities of external reality. Zhang Dongsun pursued a similar line of reasoning, claiming that the contents of our comprehension did not correspond to the actual state of the objects of recognition.

須知我們所有的感覺都不是外界存在的. 所以我們絕對無法知道外界

的’內容' (Zhang 1995, p. 171).

We should know that none of our sensations exist in the external world. Therefore, it is absolutely impossible for us to recognize the 'content' of the external world.

Both philosophers also shared the view that the spheres of reality and phenomena are ordered by the same structure. Russell (1919, p. 61) suggested that » the objective counterparts would form a world having the same structure as the phenomenal world «(Psillos 2001, p. 14). In this context, Zhang Dongsun sustained the hypothesis of the structural compatibility of both systems:

因此我承認外界有其條理; 內界 (即心) 亦有其立法 (Zhang 1995, p. 165).

Therefore, I acknowledge that the external world is ordered and that our inwardness (i.e. our mind) also functions in accordance with particular laws.

An essential difference with Russell's system can be found in the method of recognition. As we have seen, based on the supposition that we are unable to recognize the inner nature of reality, Russell concluded that inferences were the only possible method of obtaining any knowledge about it.

The only way we can attain knowledge of the latter ${ }^{6}$ is by drawing inferences from our perceptions. Assuming that similar causes (i.e. events) have similar effects (i.e. percepts) — a roughly one-to-one correspondence between stimulus and percept -Russell argues that relations between effects mirror relations between causes. (Votsist 2003, p. 880).

Zhang's understanding of consciousness is, instead, much more multi-layered, thus allowing for more dimensions in the perception and comprehension of reality:

內界的立法又分兩種, 一為直觀上的先驗方式, 一為思維上的先驗方式... 至於感覺, 則不是真正的'存在者' (Zhang 1995, p. 165).

This regulated constitution of our inwardness can also be divided into two kinds: the first can be called the a priori form of direct sensory perception, and the second the a priori form of cognition.... However, the sensations are not identical with 'existing beings'.

\footnotetext{
${ }^{6}$ Here, Russell refers to the objective reality.
} 
One reason for our inability to recognize the essence of external things "as such" is thus to be found in the very nature of their existence. For Zhang, who did not acknowledge the existence of substance, reality was a process of constant change that manifested itself in the inter-relations of particular entities. Although in his pluralistic epistemology he rejected 'substance', he still considered the dualistic theories of idealism and materialism to be completely wrong (Zhang 1995, p. 214). While elements of both approaches can be found in Zhang Dongsun's model, it cannot be identified with either one of them. As he explicitly stated (ibid), his system was not solipsistic and did not even differentiate between matter and idea or substance and phenomena. Yet, in his view, both existed objectively.

\section{The dynamic structure of time and space}

This is where Zhang's epistemology differs in a fundamental and radical way not only from Russell's theory, but even from Chan Buddhism. Taken as a whole, (Neo)-Confucian epistemology also differs in various ways from pan-structuralist approaches: while the former was based upon structural relations that were fixed and unchangeable, always tending towards the "proper" (zheng 正), Zhang's panstructuralism gives much greater priority to movement and change. In effect, he implemented the static regularity of the Neo-Confucian constructs through a new, dynamic, interferential structure of continuous, indefinable and never completely understandable amalgamations and dispersions of imagined, phenomenal and actual worlds. In this respect, his approaches recall classical Chinese (especially Daoist and Chan-Buddhist) cosmologies, as well as certain recent Western ontological systems based on Quantum Theory or the Theory of Relativity, which assume that time and space are not absolute and unchangeable. This is why his constitution of time and space is also structural.

In any case, in so doing, Zhang avoided the dilemma of a complete structural identity between the external world and the human mind. As the Greek philosopher, Stathis Psillos, notes in his study on Russell's epistemological approaches:

Precisely because Russell does not have the converse principle, he speaks of a "roughly one-to-one relation". Yet he failed to justify why this should be so. (For example, why cannot the same stimuli produce different perceptions at different times?) Further, does it make sense to speak of a "roughly one-to-one relation"? Either it is or it is not one-to-one. If it is, we have structuretransference. But if not, then we do not (Psillos 2001, p. 15).

Here, Zhang Dongsun's suppositions recall certain approaches of so-called eliminative structural realism (ibid: 22), which assumes that all we can perceive is structure. But this approach has led Western theorists to metaphysical explanations for the ontological foundations of structure (ibid), based upon the thesis that structure is primary and ontologically subsistent (Ladyman 1998, p. 420). This thesis is still the subject of intense theoretical debates: 
Note that if structures "carry the ontological weight" (French 1999, p. 204), we can only view the identity of structures as being ontologically primitive (since the notion of isomorphism requires different domains of individuals which are paired-off). But I am not sure whether we can even make sense of this primitive structural identity (Psillos 2001, pp. 22-23).

Zhang Dongsun tried to circumvent this dilemma by postulating dynamics and changeability (in time and space) as essential characteristics of his comprehension of structure. Here we can also detect the influence of certain fundamental assumptions of classical Chinese philosophy, in which all that exists manifests itself in continuous alterations of structural connections in the formation and expiration of particular existing entities, as well as the quality of their "essence" (Rošker 2012, pp. 103-110).

\section{The problem of phenomenality}

However, Zhang affirmed that our mind can only recognize certain aspects of these manifest changes. All structures are empty, for they possess neither substance, nor its qualities. The level of material being (wu 物) is thus a merely physical substantial phenomenality which cannot be equated with material substance but, at best, with structural relations and the physical laws which determine its existence. Here, one might be tempted to compare him with the radical ontological realists who claim that structure is ontologically primary because objects as such do not exist (Psillos 2006, p. 561). But Zhang's views differ substantially from such positions as well, for in his system objects do objectively exist, even though their status is not a material (physical) one in the traditional Western sense of the word. Instead, for Zhang, 'matter' is a general concept covering a total domain of many specific concepts that refer to physical properties. Hence, there is no 'matter' as such, which corresponds to our concept of this term. In his discussion of matter, Zhang Dongsun argues that matter is not the color, smell, sound or dimensions that we perceive through our senses, because these tend to be subjective. By 'matter' he intends an object's volume, density, velocity, etc. Matter thus becomes a series of physics formulas and, ultimately, there are only physical laws, but no matter (Jiang 2002 , p. 64). Zhang even suggested that we should replace the term "matter" with "physical laws", 'life' with "biological principles" and "mind" with "psychology". In other words, terms for substance as bearers of attributes should be replaced by terms for structures or orders (Rošker 2008, p. 210).

The structure of the external world was thus formed by relations between objective, existing, non-substantial entities. This concept of relation as a crucial feature of structure has also been stressed by many modern Western theorists:

Newman correctly points out "that it is meaningless to speak of the structure of a mere collection of things, not provided with a set of relations" and thus "the only important statements about structure are those concerned with the structure's make-up..." (Votsist 2003, p. 882) But what exactly did Russell mean by "structure" when he said that we can infer the structure of the 
external world from the structure of our perceptions? Discussions on "structure" or "relation-number" (Russell uses these concepts interchangeably) are invariably discussions on the structure of a relation or of a system of relations - this latter notion signifying one or more relations defined over a single domain (ibid, p. 880).

But what is also important in the context of Zhang's philosophy, are the dynamics of these structural relations that unite with one another and separate again in countless ways and on countless different levels. He compares this to cosmic emptiness, which, as in the Buddhist view, cannot be equated with "nothingness", but only with the absence of a substance, an unchangeable nature, or a selfcontained, self-sufficient being. Since the cosmos is composed exclusively of relational connections, it does not imply any independent, autonomous entity. This is also one of the main reasons why the existence of substance is impossible: the world is a series of functional relations. In Buddhist cosmology, the world, which is void in itself, is a universal, eternal and unchangeable law of causal relations (yinyuan 因緣). Zhang Dongsun equated this law with the real objectivity of being (Jiang 2002, p. 65).

\section{Perception as a result of structural changes}

The structural systems that were developed in Western philosophy during this period were based upon the supposition that we cannot recognize the real nature of (objects in) the external reality. This supposition was shared by Zhang Dongsun, but in contrast to Russell's hypothesis, his theory of comprehension is not rooted in the method of inference, which can only lead us to a recognition of the structural order of the external world.

Russell argues that relations between effects mirror relations between causes. Thus, from the structure of our perceptions we can "infer a great deal as to the structure of the physical world, but not as to its intrinsic character" [(1927) 1992, 400]. At most, what can be known is the logical form or structure, i.e., the second or higher-order properties and relations, of events in the external world (Votsist 2003, p. 880).

Zhang affirms that there must be some reason for the changes we perceive, and that this reason is to be found precisely in the factual structural changes of the external reality, which are consciously comprehended as structural changes by the correlation of the external order with the laws of the mind. This also holds true in the opposite sense: each change in our consciousness is structurally conditioned and has likewise been expressed in structural changes of the external order. In this respect, Zhang's assumptions were founded upon the interdependence, co-relativity and interactivity of the inner and external worlds. Furthermore, the Chinese theorist never considered atomicity, continuity and creativity as elements which belonged exclusively to the external order; rather, he saw these structural qualities as a kind of bridge, linking the external and the inner sphere (Zhang 1995, pp. 170-171).

Zhang Dongsun clearly proceeded not only from modern European (especially Kantian) philosophy, but also from certain specific foundations of the Chinese 
tradition of thought. In addition to the structural compatibility of the external world and the mind, which can already be found in ancient Chinese epistemology, his work was also greatly influenced by Chan Buddhism, which was defined by the concepts of the emptiness of all phenomena, and their illusory, transitory nature that not only included external actuality, but the self and its identity. Thus, one of the basic differences between Western structural realism (Psillos 2001, p. 513) and Zhang Dongsun's pan-structural system is the latter's view that not only is structure all we can recognize, but that the external world includes no substantial objects. Consequently, the world is situated within a non-substantial structure that is (in a strictly physical sense) empty, since it exists as continuous change.

A logical consequence of the epistemological structural realism of the Western type is the assumption that the reality of what is not empirically perceivable can be inferred from the actuality of the empiric world. Russell, for example, claimed that in terms of the knowability of the objective external world, given that phenomena and substance shared a common structure, it was not only possible, but also legitimate to infer the latter from the former.

Russell (1919, p. 61) suggested that the objective counterparts formed a world having the same structure as the phenomenal world, (a fact which would allow us) to infer from phenomena the truth of all propositions that could be stated in abstract terms and which were known to be true of phenomena. (Psillos 2001, p. 514).

However, traditional Chinese analogical inferences were, from the time of the most ancient disputes, defined by semantic connotations (Rošker 2012, pp. 16-17) which could place in question the very nature of the formal inferences that have dominated traditional European logic. We must also bear in mind that Zhang's panstructuralism rested upon the structural compatibility, but not the structural identity of the external and internal world. In his view, it was precisely the structure of comprehension which was much more complex, and it was only for the sake of facilitating his exposition that he maintained the schematic division between the subject and object of comprehension. As is well known, both poles are seen by naturalistic epistemologies as defining the process of comprehension and the theoretical mode of its framework. Zhang, however, posited the existence of vital connections between the subject (with its empirical mechanisms), on the one hand, and the objective sphere of the empirically (or rationally) unseizable world, on the other ${ }^{7}$ People commonly think that there is nothing between these two poles, that between them there is only empty space. This would mean that the subject and object of recognition were in direct relation with each other. But I believe that there are many things between them, that this "middle" in other words, is very complex.

In this context, he was definitely guided by certain, specific implications of traditional Chinese concepts of knowledge or cognizance that are rooted in a model of structural relations, relations which are essentially not grounded upon a formal equivalence but, at most, upon the compatibility of the structures they are forming

\footnotetext{
這個中間普通人認為沒有東西存在, 即好像是空的. 所以能知與所知得以直接發生關係. 我則以 為在這個中間 內卻有許多東西，換言之，即是複雜的 (Zhang 1995, p. 213).
} 
(ibid, p. 103). Therefore, they cannot be seized by formal, but only through semantic inferences.

\section{Methods of comprehension}

With respect to the methods of comprehension, Zhang was following the traditional Chinese concept of qualitative knowledge as it had already been defined by his contemporary Xiong Shili熊十力(1885-1968) who, based upon a solid command of Confucian and Daoist approaches, denoted it as a qualitative understanding (xing zhi 性智):

性智者, 即是真的自己的覺悟. 此中真的自己一詞, 即為本體 即此本體, 以其為吾人所以生之理而言, 則亦名真的自己. 即此真己, 在量論中說明覺 悟，即所謂性智...這種覺悟雖不離感官經驗，要是不滯於感官經驗而恒自 在離系的 (Xiong 1992, p. 249).

Qualitative understanding is awareness of self. The real self in this sense can be called substance [...] From the viewpoint of the structure which enables us to live, it could also be denoted as the real self. ${ }^{8}$ In the domain of quantitative methodologies, this real self is explained by consciousness and is also called qualitative understanding. Although this kind of consciousness is not separated from sensory experiences, it is not limited to such experience; moreover, it always exists independently, outside of all systems.

The second type of comprehension, which also includes inferences (among other elements) and functions as a qualitative understanding or habituated mind, was called quantitative knowledge (liangzhi 量智) ${ }^{9}$ by Xiong Shili.

This mode of quantitative understanding, which represented the basis of scientific comprehension for Xiong (Rošker 2008, p. 198), likewise implied inferring from fixed, eternally "valid" assumptions. But the concept of qualitative understanding as described by Xiong and which is rooted in realistic currents within Confucian philosophy ${ }^{10}$ cannot be equated with many other traditions of Confucian thought as developed in the solipsistic discourses of later Daoism and the Confucian School of Mind (xin xue 心學). For the latter, in fact, the external world had no objective existence, but was merely represented through numerous transformations within our mind.

In essence, Zhang Dongsun's pan-structuralism also belongs to the qualitative modes of understanding. Since it proceeds from the non-substantiality and continuous changing of all mutually connected structural patterns, the correlations between them are also non-substantial and not completely accessible through logic. None of these correlations can be said to have the statute of a rigid premise from which valid inferences can be drawn. Nonetheless, these correlations are the (only)

\footnotetext{
8 Another possible translation of this term is "the True Self".

9 Due to their identical pronunciation, we should not confuse Xiong's term liangzhi 量智, or quantitative understanding, with the Neo-Confucian term liang zhi 良知, which means innate knowledge).

${ }^{10}$ In this context, Neo-Confucian theories of knowledge are especially valuable, especially when based on the binary category connecting the exploration of things (gewu 格物) with perfect or ultimate knowledge (zhi zhi 至知).
} 
possible connection between the self and the Other. Knowledge is thus also a relation, for its formation has a strong impact upon these two poles of existence and comprehension. Since the structural connection between them is compatible with the structural connection between language and meaning (yan yi 言意), knowledge can be semantically transmitted.

\section{Conclusion}

Contemporary Confucian discourses often try to fill the gap between these two levels of existence by endowing it with values; Zhang Dongsun, however, was not particularly concerned with the ethical consequences of his epistemological model. While classical Chinese philosophy was chronically obsessed with ethical issues, Zhang's philosophy bears the clear imprint of classical Chinese structural worldview (Rošker 2012, pp. 3-11). His view of the process of comprehension is based upon the traditional Chinese worldview that presupposes structural interferences ${ }^{11}$ between the mental and actual worlds. He believed these worlds to be equally part of the continuous amalgamations and dispersions of various mutually (un)adjusted structural patterns by which actuality is formed. In this context, time and space are merely functions of each other. While the latter is characterized by constellations of spatial forms that, in varying from instant to instant, form the geometrical space, time (in the form of continuity) is incorporated in us by sudden, momentary sparks of awareness. While even this continuity was fictitious and transitory for Zhang, due to its semantic implications it still had a sufficient duration to become the only effective link between the mind and the external world.

Acknowledgments This article is based on research that was funded by the Taiwanese Chiang ChingKuo Foundation.

\section{References}

French, S. (1999). Models and Mathematics in Physics. In J. Butterfield \& C. Pagonis (Eds.), From Physics to Philosophy (pp. 187-207). Cambridge: Cambridge University Press.

Jiang, X. (2002). Zhang Dongsun: Pluralist Epistemology and Chinese Philosophy. In C. Y. Cheng \& N. Bunnin (Eds.), Contemporary Chinese Philosophy (pp. 57-81). Oxford: Blackwell Publishers.

Ladyman, J. (1998). What is structural realism? Studies in History and Philosophy of Science, 29, 409_ 424.

Psillos, S. (2001). Is structural realism possible? Philosophy of Science, 68(3), 13-24.

Psillos, S. (2006). The structure, the whole structure, and nothing but the structure? Philosophy of Science, 73(4), 560-570.

Rošker, J. (2008). Searching for the way-theory of knowledge in pre-modern and modern China. Hong Kong: Chinese University Press.

Rošker, J. (2012). Traditional Chinese philosophy and the paradigm of structure (Li). Newcastle upon Tyne: Cambridge Scholars Publishing.

Russell, B. (1919). Introduction to mathematical philosophy. London: George Allen and Unwin.

\footnotetext{
11 In Chinese tradition, such interferences were conditioned by circulation (tong 通), (Rošker 2012, p. 106).
} 
Russell, B. (1957, 1st ed. 1918). The relation of sense-data to physics. In Mysticism and logic (pp. 140273). New York: Doubleday Anchor.

Russell, B. (1992, 1st ed. 1927). The analysis of matter. London: George Allen and Unwin.

Russell, B. (2000). Uncertain paths to freedom: Russia and China. In R. A. Rempel \& B. Haslam (Eds.), The collected papers of Bertrand Russell (Vol. 15, pp. 1919-1922). London: Routledge.

Votsist, I. (2003). Is structure not enough? Philosophy of Science, 70(5), 879-890.

Xiong, S. (熊十力) (1992). Xiong Shili lunzhu ji zhi yi 熊十力論著集之一 (The collected works of Xiong Shili). Part 1: Xin weishi lun. Beijing: Zhonghua shuju.

Zhang, D. (張東荪) (1929). Xin zhexue luncong 新哲學論叢 (An anthology of new philosophy). Beijing: Shangwu yinshuguan.

Zhang, D. (張東荪) (1995). Lixing yu liangzhi-Zhang Dongsun wenxuan 理性與良知 - 張東荪文選 (Reason and original knowledge-selected works of Zhang Dongsun), In Zhang Rulun (Eds.). Shanghai: Shanghai Yuandong chuban she.

Zhang, Y. (張耀南) (2000). Cong ershi shiji Zhongguo zhexue kan Zhang Dongsun zhi 'jiagou lun' 從二 十世紀中國哲學看張東荪之 ‘架構 論' (Zhang Dunsun's 'Structural theory' from the viewpoint of chinese philosophy of the 20th century). Xueshu jie, 81(2), 143-150. 